\title{
Analysis of Academic Self-Efficacy Levels of University Students Doing Sport Regularly and those Not Doing Sport Regularly
}

\author{
Egemen Ermiş \\ Tasar Dogu Sports Sciences Faculty, Ondokuz Mayzs University, Samsun, Turkey. \\ Email:egemen.ermis@omu.edu
}

\section{Abstract}

The purpose of this study is to analyze academic self-efficacy levels of university students studying in different departments according to their states of doing regular sports and some variables. 299 students, 153 females and 146 males, studying in different departments of Samsun Ondokuz Mayıs University participated in the study voluntarily. "Academic Self-efficacy Scale" which was developed by Owen and Froman (1988) and adapted to Turkish by Ekici (2012) and which included 33 questions and 3 sub-dimensions (social status, cognitive practices, technical skills) was used in the study to find out academic self-efficacy levels of students in terms of different variables. SPSS 22.0 program was used for statistical analysis. When the results were analyzed, statistically significant difference was found only in social status sub-dimension in terms of the variables of gender and grade $(\mathrm{p}<0.05)$. No significant difference was found in other subdimensions for both variables $(\mathrm{p}>0.05)$. When academic self-efficacy levels were analyzed in terms of students' states of doing regular sports, statistical significance was not found in any of the subdimensions $(p>0.05)$. As a conclusion, it was found that the state of doing sports regularly did not have an influence on academic self-efficacy level. This result is thought to occur due to the fact that the experimental group in the present study does not consist of only students from the faculty of sport sciences, but also from students studying in different departments of the university.

Keywords: Academic self-efficacy, Sport, University students.

Citation | Egemen Ermiş (2019). Analysis of Academic SelfEfficacy Levels of University Students Doing Sport Regularly and those Not Doing Sport Regularly. Asian Journal of Education and Training, 5(2): 324-328.

History:

History:

Revised: 7 March 2019

Accepted: 16 April 2019

Published: 31 May 2019

Licensed: This work is licensed under a Creative Commons

Attribution 3.0 License (cc)

Publisher: Asian Online Journal Publishing Group
Funding: This study received no specific financial support

Competing Interests: The author declares that there are no conflicts of interests regarding the publication of this paper.

Transparency: The author confirms that the manuscript is an honest, accurate, and transparent account of the study was reported; that no vital features of the study have been omitted; and that any discrepancies from the study as planned have been explained.

Ethical: This study follows all ethical practices during writing.

\section{Contents}

1. Introduction.

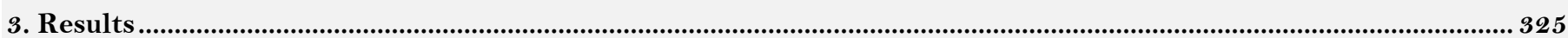

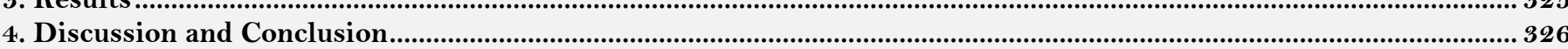

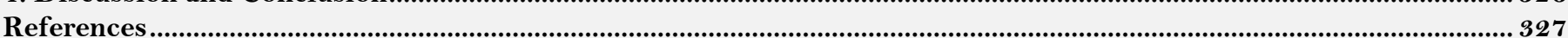




\section{Introduction}

Sport is among the most basic physical activities of our day. Ten thousands of people doing sport in various parts of the world every day are interested in sportive activities, even if in different branches. Even though we are not aware of it, sport activities have always been intertwined with vital activities and social life in almost every period of human history. Thus, it is not very possible to take sport out of social life (Dever, 2010; Cavusoglu et al., 2017; Tekeli, 2017; Dogan et al., 2018; Kabadayı et al., 2018). Performance that people will show in both normal life conditions and also in sport is directly associated with self-efficacy. However, self-efficacy does not mean an individual's showing the performance expected from him/her (Çuhadar et al., 2013). Self-efficacy is the basic concept of social learning process and it can be defined as an individual's being aware of his/her own capacity. This awareness does not cause an individual to realize what he/she has, but to realize what he/she can do with his/her existing abilities (Luszczynska et al., 2005). Self-efficacy has been defined as an individual's organizing the necessary activities to show a specific performance and self-perception, judgement and belief about his/her capacity to successfully perform these. In other words, self-efficacy is the competence an individual views with himself/herself about to what extent he/she can overcome the problems encountered. It is the positive attitudes an individual develops against difficulties he/she might encounter [4]. Since the beginning of 1990s, self-efficacy concept has been the research subject of many scientists (Kurt, 2012; Alemdağ et al., 2014; Oral and Aktop, 2014; Kılıç et al., 2015; Sevilmiş and Şirin, 2016; Şirin and Duman, 2018). Researchers have shown that individuals or groups with a high belief of self-efficacy have high level of performance (Turan et al., 2016). Individuals with high self-efficacy notion set higher goals for themselves and thus their motivation levels increase and they show a better performance (Shea and Guzzo, 1987; Guzzo et al., 1993; Bandura, 1997; Gibson, 1999; Gibson et al., 2000; Bray, 2004; Myers et al., 2004).

Academic achievement is claimed to be associated with many factors directly. In addition to cognitive characteristics, affective characteristics can also be discussed as one of these factors. When considered from this point of view, it can be thought that affective factors such as attitude, self-efficacy, motivation and anxiety can influence many factors, especially students' eagerness and interest for the lesson and in return this can influence students' performance and thus their academic achievement (Sevilmiş and Şirin, 2016). Academic self-efficacy is an individual's subjective belief that he/she can successfully fulfil the assigned academic missions in predetermined levels (Bong, 2004). During the years university students are educated, their academic duties and responsibilities increase and as a result, it is very important for them to use time efficiently and effectively. Within this context, a student with high academic self-efficacy has very strong attitudes and behaviours about the academic duty he/she is assigned (Biricik, 2015). Based on all this information, the purpose of the present study is to analyze the academic self-efficacy levels of students who are doing sport regularly and those who are not doing sport regularly in terms of different variables.

\section{Material and Method \\ 2.1. Study Design}

A total of 299 students, 153 females and 146 males, studying in different departments of Samsun OndokuzMayıs University were included in the study. In the study, "Academic Self-efficacy Scale" which had 33 questions and 3 sub-dimensions and which was developed by Owen and Froman (1988) and was adapted to Turkish by Ekici (2012) was used to find out the academic self-efficacy of students according to different variables. The subjects in the study filled in voluntary participation form and it was emphasized that it was important for them to read the questions and fill in the questionnaire form carefully for the reliability and validity of the study. The subjects' states of doing regular sport and some of their demographic information were found with the personal information form prepared by the author.

\subsection{Academic Self-Efficacy Scale}

In the present study, Academic Self-efficacy Scale" which had 33 questions and 3 sub-dimensions (social status, cognitive practices, technical skills) and which was developed by Ekici (2012) was used to find out the academic self-efficacy of students according to different variables. The scale was a 5-Likert type scale and it was scored as quite a lot (5 points), a lot (4 points), partially ( 3 points), a few ( 2 points) and quite a few ( 1 point). According to the analysis results conducted to test the reliability level of the scale used in the study, Cronbach alpha coefficients were found as 0.77 (social status), 0.79 (cognitive practices) and 0.75 (technical skills). In addition, total internal coefficient of the scale was found as 0.77 . These results show that the results of the scale are acceptable.

\subsection{Data Analysis}

Statistical analyses were conducted with SPSS version 22.0 software. Shapiro-Wilk test was used to analyze normality assumption. In case of normally distributed variables, groups of two were analyzed with independent $t$ test, while groups of more than two were analyzed with ANOVA test. In case of variables which were not normally distributed, groups of two were analyzed with Mann Whitney U test, while groups of more than two were analyzed with Kruskall Wallis test. A p value of less than 0.05 was assessed as statistically significant.

\section{Results}

Table 1 shows the demographic information of the subjects. According to the table, 146 (48.8) of the subjects who participated in the study were male, while $153(51.2 \%)$ were female. 48 (16.1\%) first year students, $31(10.4 \%)$ second year students, $27(9.1 \%)$ third year students and $192(64.4 \%)$ fourth year students participated in the study. In terms of doing regular sport, $128(42.8 \%)$ students were found to do regular sport, while it was found that 171 $(57.2 \%)$ students did not do regular sport. 


\begin{tabular}{c|c|c|c}
\multicolumn{2}{c}{ Table-1. Participants' Demographic Informations. } & N & \% \\
\hline Variables & & 146 & $\% 48.8$ \\
\hline Gender & Male & 153 & $\% 51.2$ \\
\hline Year of study & Female & 48 & $\% 16.1$ \\
\hline & 1st year & 31 & $\% 10.4$ \\
\hline & 2nd year & 27 & $\% 9.1$ \\
\hline Regular sport status & 3rd year & 192 & $\% 44.4$ \\
\hline & 4th year & 128 & $\% 57.2$ \\
\hline Total & Yes & 171 & $\% 100$ \\
\hline
\end{tabular}

Table-2.Comparison of participants' academic self-efficacy according to gender variable.

\begin{tabular}{|c|c|c|c|c|c|}
\hline Sub-dimensions & Gender & $\mathbf{N}$ & Ave.Rank & Stand.Test Stat. & $\mathbf{P}$ \\
\hline Social Status & Male & 146 & 160.66 & \multirow{2}{*}{-2.086} & \multirow{2}{*}{$0.037 *$} \\
\hline & Female & 153 & 139.82 & & \\
\hline \multirow{2}{*}{ Cognitive Practices } & Male & 146 & 141.70 & \multirow{2}{*}{1.622} & \multirow{2}{*}{0.105} \\
\hline & Female & 153 & 157.92 & & \\
\hline \multirow[t]{2}{*}{ Technical Skills } & Male & 146 & 156.08 & \multirow{2}{*}{-1.194} & \multirow{2}{*}{0.233} \\
\hline & Female & 153 & 144.20 & & \\
\hline
\end{tabular}
$* \overline{\mathrm{p}}<0.05$.

In Table 2, when the subjects' academic self-efficacies were compared in terms of the gender variable, statistically significant association was found between academic self-efficacies of female and male students in terms of social status $(\mathrm{p}<0.05)$. However, no statistical significance was found in cognitive practices and technical skills sub-dimensions $(\mathrm{p}>0.05)$.

Table-3. Comparison of participants' academic self-efficacy according to their year of study.

\begin{tabular}{|c|c|c|c|c|c|c|}
\hline Sub-dimensions & Year & $\mathbf{N}$ & Total square & Mean square & $\mathbf{F}$ & $\mathbf{P}$ \\
\hline \multirow{4}{*}{ Cognitive practices } & 1st year & 48 & 2.589 & 0.863 & \multirow{4}{*}{2.402} & \multirow{4}{*}{0.068} \\
\hline & 2nd year & 31 & 105.606 & 0.359 & & \\
\hline & 3rd year & 27 & 108.194 & & & \\
\hline & 4th year & 192 & & & & \\
\hline & & $\mathrm{N}$ & Average & Ave. Rank & Chi square & $\mathrm{P}$ \\
\hline \multirow{4}{*}{ Social Status } & 1st year & 48 & \multirow{4}{*}{3.0601} & 143.70 & \multirow{4}{*}{8.414} & \multirow{4}{*}{$0.038 *$} \\
\hline & 2nd year & 31 & & 109.35 & & \\
\hline & 3rd year & 27 & & 158.76 & & \\
\hline & 4th year & 192 & & 156.13 & & \\
\hline \multirow{4}{*}{ Technical Skills } & 1st year & 48 & \multirow{4}{*}{2.9186} & 157.51 & \multirow{4}{*}{2.074} & \multirow{4}{*}{0.557} \\
\hline & 2nd year & 31 & & 136.98 & & \\
\hline & 3rd year & 27 & & 134.11 & & \\
\hline & 4th year & 192 & & 151.68 & & \\
\hline
\end{tabular}

When the academic self-efficacy levels of the participants were compared in terms of their year of study, while statistical significance was found in social status sub-dimension $(\mathrm{p}<0.05)$, no significant difference was found in other sub-dimensions ( $\mathrm{p}>0.05)$ Table 3.

Table-4. Comparison of participants' academic self-efficacy according to their status of doing sport regularly.

\begin{tabular}{|c|c|c|c|c|c|}
\hline Sub-dimensions & Regular sport & $\mathbf{N}$ & Ave. Rank & Stand.Test Stat. & $\mathbf{P}$ \\
\hline \multirow{2}{*}{ Social Status } & Yes & 127 & 158.10 & \multirow{2}{*}{-1.487} & \multirow{2}{*}{0.137} \\
\hline & $\mathrm{No}$ & 171 & 143.11 & & \\
\hline \multirow{2}{*}{ Cognitive Practices } & Yes & 127 & 143.95 & \multirow{2}{*}{0.959} & \multirow{2}{*}{0.338} \\
\hline & No & 171 & 153.62 & & \\
\hline \multirow{2}{*}{ Technical Skills } & Yes & 127 & 151.65 & \multirow{2}{*}{-0.374} & \multirow{2}{*}{0.709} \\
\hline & No & 171 & 147.90 & & \\
\hline
\end{tabular}

$\mathrm{p}>0.05$.

Table 4 compares the participants' academic self-efficacy according to their states of doing sport regularly. When the results are analyzed statistically, no significant difference was found in all of the sub-dimensions between the academic self-efficacy of the students who did sports regularly and those who did not ( $>0.05)$.

\section{Discussion and Conclusion}

When the results of our study were analyzed in general, statistical significance was found in social status subdimension in favour of male students in terms of the gender variable $(\mathrm{p}<0.05)$. In addition, when analyzed in terms of year of study, statistical significance was found in social status sub-dimension $(p<0.05)$. No significance was found between the participants' academic self-efficacy in terms of their state of doing sport regularly ( $>0.05)$.

There are a great number of studies in literature which have measured academic self-efficacy of different groups. However, no studies have been found which have examined the academic self-efficacy levels of university students in terms of their states of doing sport regularly. When studies on academic self-efficacy were examined, some of these studies were found to report significance between genders in terms academic of self-efficacy (Çakır et al., 2006; Özsüer et al., 2011; Oğuz, 2012; Tabancalı and Çelik, 2013; Kılıç et al., 2015). These studies have proven 
that different gender groups can show different results. However, all results have shown clearly that academic selfefficacy of only a single gender is not high. That is, in some studies male participants were found to have high averages, while female participants were found to have high averages in some others. For example, while Er and Gürgan (2011) reported that female participants had higher academic self-efficacy belief levels, Akbay (2009) and Durdukoca (2010) reported that male participants had higher academic self-efficacy levels. The fact that academic self-efficacy levels differed according to gender variable has brought up the necessity of avoiding generalizing psychological components that can change depending on factors such as different occupations or socio-economic structure. Sandıkçı and Öncü (2013) also supported this view. Studies examining the academic self-efficacy of occupations related with sport showed the following results. In a study conducted on students studying in physical education and sport department, Biricik (2015) found differences between groups and unlike the present study, found that female students had high rates. In a study conducted by Varol (2007) to find out self-efficacy of students of physical education and sport teaching department, no difference was found between female students and male students. Bozkurt (2013)also did not find any difference between female students and male students in a study conducted on prospective teachers of physical education. In terms of self-efficacy levels of university students who were not doing sport, Satici (2013) concluded that male students had higher academic self-efficacy when compared with female students. In some of the studies conducted on occupations related with sport, female participants were found to have high self-efficacy scores, while male participants were found to have high self-efficacy scores in others (Vurucu, 2010; Ciftçi, 2013).

In the present study, no statistically significant difference was found between the academic self-efficacy levels of students in terms of the state of doing sport regularly $(\mathrm{p}>0.05)$. However, when studies in literature were examined in general, Biricik (2015) found that individuals who did sport regularly had higher scores when compared with those who did not and similarly, results of a great number of other studies showed that regular sports had positive effects on academic self-efficacy (Ünlü, 2008; Balyan, 2009; Baştuğ and Kuru, 2009; Kafkas et al., 2010; Bozkurt, 2013). Based on all these results, it is thought that the reason why there is no significant difference between self-efficacy scores of students doing sport regularly and those not doing sport regularly results from the fact that the experimental group consists of not only students studying in the faculty of sport sciences, but also of students studying in different departments of the university. In all of the studies found in literature which showed significance between genders, the participants consisted of students studying in departments of sport sciences faculties or schools of physical education and sport. Sport phenomenon is a very important structure that exists in almost every period of life and it affects the human life with all its aspects. Everyone who does sports gains a status more or less in the social structure. The power of sport is measured with its being a means of socialization and its role of keeping people together. Based on this information, when the socializing power of sport is considered, it is thought as a possible result for students doing sport to have higher results than students who do not.

\section{References}

Akbay, S., 2009. Academic procrastination behavior in university students by gender: Role of academic motivation, academic self-efficacy and academic loading styles. Unpublished Master's Thesis. University of Mersin. Social Sciences Institute.

Alemdağ, C., E. Öncü and A. Yılmaz, 2014. Academic motivation and academic self-efficacy of physical education teacher candidates. Journal of Sport Sciences, 25(1): 23-35.

Balyan, M., 2009. Comparison of the attitudes towards physical education course, social skills and self-efficacy levels of secondary level secondary and secondary education institutions. Published PhD Thesis. İzmir: Ege University Institute of Health Sciences.

Bandura, A., 1997. Self-efficacy. The exercise of control. New York: W. H. Freeman Company.

Baştuğ, G. and E. Kuru, 2009. A research on the body levels of women athletes and their roles on gender roles. Journal of Gazi Faculty of Education, 29(2): 533-555.

Biricik, Y., 2015. Investigation of the academic self-efficacy of the students in physical education and sports departments. Erzurum: Atatürk University Institute of Social Sciences Department of Sports Management.

Bong, M., 2004. Academic motivation in self-efficacy, task value, achievement goal orientations, and attributional beliefs. The Journal of Educational Research, 97(6): 287-298.Available at: https://doi.org/10.3200/joer.97.6.287-298.

Bozkurt, M.T., 2013. Investigation of teachers' self-efficacy of physical education teachers. Ankara: Gazi University, Institute of Educational Sciences, Department of Physical Education and Sports.

Bray, S.R., 2004. Collective efficacy, group goals, and group performance of a muscular endurance task. Small Group Research, 35(2): 230238.Available at: https://doi.org/10.1177/1046496403260531.

Çakır, Ö., A. Kan and Ö. Sünbül, 2006. Evaluation of attitude and self-efficacy of teaching profession information and non-thesis graduate programs. Mersin University Faculty of Education Journal, 2(1): 36-47.

Cavusoglu, G., A. Yılmaz, M. Kabadayı, S. Abacı and M. Tasmekteplıgil, 2017. Comparison of narcissism levels of students in the faculty of sports sciences in terms of some demographic variables. Turkish Journal of Sport and Exercise, 19(2): 150-156.

Ciftçi, S., 2013. Determination of self-efficacy status of sports managers. Published PhD Thesis. Bolu: Abant Izzet Baysal University, Institute of Social Sciences.

Çuhadar, C., Ş. Gündüz. and T. Tanyeri, 2013. An investigation of the relationship between the students in the department of computer education and instructional technology teaching approaches and academic self-efficacy perceptions. Mersin University Faculty of Education Journal, 9(1): 251-259.

Dever, A., 2010. Sports sociology. Istanbul: Title Publications.

Dogan, E., A.K. Yilmaz, M. Kabadayi and M.H. Mayda, 2018. An investigation of socialization and happiness levels of students studying in different faculties with sports science students. Journal of Kafkas University Institute of Social Sciences, 22(1): 403-411.

Durdukoca, Ş., 2010. An investigation of academic self-efficacy perceptions of classroom teacher candidates in terms of various variables. Abant Izzet Baysal University Journal, 10(1): 69-77.

Ekici, G., 2012. Lilik academic self efficacy scale: Turkish adaptation. Validity and Reliability Study Geç. Hacettepe Univer sity Journal of Education Faculty, 43(1): 174-185.

Er, K. and U. Gürgan, 2011. The relationship between teachers' self-efficacy perceptions and attitudes towards copying. Balıkesir University Journal of Institute of Social Sciences, 14(26): 1-18.

Gibson, C., A. Randel and P. Early, 2000. Understanding group efficacy. Group And Organization Management, 25: 67-98.Available at: https://doi.org/10.1177/1059601100251005.

Gibson, C.B., 1999. Do they do what they believe they can? Group efficacy and group effectiveness across tasks and cultures. Academy of Management Journal, 42(2): 138-152.Available at: https://doi.org/10.5465/257089.

Guzzo, R.A., P.R. Yost, R.J. Campbell and G.P. Shea, 1993. Potency in groups: Articulating a construct. British Journal of Social Psychology, 32(1): 87-106.Available at: https://doi.org/10.1111/j.2044-8309.1993.tb00987.x.

Kabadayı, M., A.K. Yılmaz and H.M. Mayda, 2018. Investigation of social self-efficacy levels of the students of the faculty of sport sciences. International Congress of Sports for All and Welness. 
Kafkas, M.E., M. Açak, B. Çoban and T. Karademir, 2010. The relationship between self-efficacy perceptions and professional concerns of physical education prospective teachers. Inonu University Faculty of Education Journal, 11(2): 93-111.

Kılı̧, S.K., H. Cihan and Ö. Erman, 2015. Metacognitive learning strategies of physical education pre-service teachers. Academic self-efficacy and attitudes towards teaching profession. Journal of Sport Sciences, 26(3): 77-89.

Kılıç, S.K., H. Cihan and Ö. Erman, 2015. Metacognitive learning strategies, academic self-efficacy and attitudes towards teaching profession. Journal of Sport Sciences, 26(3): 77-89.

Kurt, T., 2012. Teachers' self efficacy and collective competence perceptions. Journal of Turkish Educational Sciences, $10(2): 21-27$.

Luszczynska, A., B. Gutierrez-Dona and R. Schwarzer, 2005. General self-efficacy İn various domains of human functioning. Evidence from five countries. International Journal of Psychology, 40(2): 80-89.Available at: https://doi.org/10.1080/00207590444000041

Myers, N., D.L. Feltz and S.E. Short, 2004. Collective efficacy and team performance: A longitudinal study of collegiate football teams. Group Dynamics, 8(2): 126-138.Available at: https://doi.org/10.1037/1089-2699.8.2.126.

Oğuz, A., 2012. Academic self-efficacy beliefs of prospective primary school teacher. Anadolu Journal of Educational Sciences, $2(2): 15-28$.

Oral, C. and A. Aktop, 2014. Exercise self-efficacy levels and exercise behavioral change levels of university students. International Journal of Science Culture and Sport, 2(3): 15-27.

Owen, S. and R.D. Froman, 1988. Scale of self-efficacy. New Orleans. L.A: Business Meeting in Office.

Özsüer, S., G. İnal, Ö. Uyanık and M. Ergün, 2011. An investigation of academic self-efficacy levels of students studying at Afyon Kocatepe University. Journal of Social Sciences, 13(2): 113-125.

Sandıkçı, M. and E. Öncü, 2013. Determination and comparison of competency perceptions and attitudes of teacher candidates in physical education and other areas related to teaching profession. Pamukkale Journal of Sport Sciences, 4(1): 135-151.

Satıcı, A.S., 2013. An investigation of university students' academic self-efficacy in terms of variables. Unpublished Master's Thesis. Eskisehir: Anadolu University Institute of Educational Sciences.

Sevilmiş, A. and E.F. Sirin, 2016. Academic success in the students of the faculty of sport sciences: University quality of life. Academic motivation and the role of academic self-efficacy. Journal of Physical Education and Sports Sciences, 14(1): 31-44.

Shea, G.P. and R.A. Guzzo, 1987. Group effectiveness: What really matters? Sloan Management Review, 28(3): 25.

Şirin, E.F. and S. Duman, 2018. Academic delay behavior in the students of physical education and sports school by gender: The role of general procrastination and academic self-efficacy. Turkish Journal of Sport Sciences, 1(1): 1-10.

Tabancall, E. and K. Çelik, 2013. The relationship between academic self-efficacy and teacher self-efficacy of prospective teachers. Journal of Human Sciences, 10(1): 1167-1184.

Tekeli, Ş.C., 2017. Comparison of social appearance anxiety and academic self-efficacy levels of physical education and sports teacher candidates and other teacher candidates. Master's Thesis. Bartin University. Institute of Educational Sciences.

Turan, M.B., B. Karaoglu, K. Kaynak and P. Osman, 2016. Special aptitude exams of candidates entering the general self-adequacy levels according to some variables. Journal of Sport Sciences Research, 1(1): 17-26.

Ünlü, H., 2008. The competences of physical education teachers and classroom management behaviors. Published PhD Thesis). Ank ara: Gazi University Institute of Educational Sciences.

Varol, B., 2007. The competencies of the physical education and sports department students about the profession of profession, Nigde example. Niğde: Niğde University Institute of Social Sciences Department of Educational Sciences.

Vurucu, F., 2010. Vocational high school profession selection proficiency factors affecting the choice of profession. Unpublished Master's Thesis. Istanbul: Yeditepe University, Institute of Social Sciences. 